\title{
REDIMENSIONANDO A CONTRIBUIÇÃO DE ROBERTO SIMONSEN À CONTROVÉRSIA DO PLANEJAMENTO (1944-1945)*
}

\author{
REEXAMINING ROBERTO SIMONSEN'S \\ CONTRIBUTION TO THE CONTROVERSY ON \\ ECONOMIC PLANNING (1944-1945)
}

\author{
Luiz Felipe Bruzzi Curi \\ Universidade de São Paulo, São Paulo, Brasil, luizfelipelfbc@gmail.com
}

Alexandre Mendes Cunha

Universidade Federal de Minas Gerais, Belo Horizonte, Brasil, alexandre@cedeplar.ufmg.br

\begin{abstract}
Resumo. A controvérsia do planejamento (1944-1945), entre Roberto Simonsen e Eugênio Gudin, é um momento privilegiado para o estudo da história das ideias econômicas. A participação de Roberto Simonsen nessa discussão pode ser revista e lida de maneira enriquecedora numa perspectiva de história das ideias. Este artigo investiga a especificidade teórica que distingue a abordagem de Simonsen em relação à de Gudin, postulando que o primeiro entra no debate pela via da história econômica. Sua abordagem está em sintonia com discussões teóricas do final da segunda guerra, levadas a cabo nas próximas décadas pela economia do desenvolvimento no Brasil. A inserção da contribuição de Simonsen no contexto histórico da controvérsia abre novas possibilidades de leitura desse debate essencial na construção de um pensamento econômico no Brasil.
\end{abstract}

Palavras-chave: planejamento; difusão internacional de ideias; era Vargas; industrialização.

Abstract. The controversy on economic planning (1944-1945), between Roberto Simonsen and Eugênio Gudin, is a distinguished moment for the study of the history of economic ideas. Roberto Simonsen's participation in this discussion can be revisited and read in an enriching way if a history-of-ideas perspective is adopted. This paper investigates the theoretical specificity that distinguishes Simonsen's approach from Gudin's, arguing that the former joins the debate by means of economic history. His approach was in tune with theoretical questions relevant at the end of World War II, which came to be debated by development economics in Brazil over the next decades.

* Versões preliminares deste artigo foram apresentadas no $39^{\circ}$ Encontro Nacional de Economia/Associação Nacional dos Centros de Pós-Graduação em Economia (ANPEC) (Foz do Iguaçu, 2011) e no Seminário Hermes \& Clio, Faculdade de Economia, Administração e Contabilidade da Universidade de São Paulo (São Paulo, 2012). Os autores agradecem os comentários e sugestões de Carlos Suprinyak e Flávio Saes.

Am. Lat. Hist. Econ., año 22, núm. 3, septiembre-diciembre, 2015, pp. 76-107 
Placing Simonsen's contribution in the historical context of the controversy opens new possibilities of reading this debate, which is essential for the construction of an economic thought in Brazil.

Key words: economic planning; international diffusion of ideas; Vargas administration; industrialization.

Artigo recebido: 29 de junho de 2014. Artigo aceito: 6 de novembro de 2014 .

\section{INTRODUÇÃO}

$\mathrm{E}$

ncontrar divergências de ideias entre os economistas é algo corriqueiro, seja qual for o tema ou período em questão. Não obstante, o estabelecimento de efetivos debates públicos confrontando posicionamentos diferentes é quase sempre um momento excepcional e que se oferece como uma fonte preciosa ao historiador do pensamento econômico. As possibilidades analíticas que esses debates podem nos oferecer ultrapassam as próprias ideias debatidas e se articulam aos contextos da história econômica e política que lhes servem de pano do fundo. Mas, ao mesmo tempo, permitem avaliar que a simples ocorrência de um debate público entre economistas com posições divergentes sobre um tema de relevo implica de saída o reconhecimento mútuo da outra parte como um interlocutor legítimo. Isto por si só é algo inviável em momentos nos quais se estabelece uma hegemonia de uma determinada corrente de pensamento sobre as demais. Ter em conta questões como esta ajuda a fugir de anacronismos e analisar os debates com a devida referência ao tempo e lugar em que se desenvolveram. Em nosso exercício presente de buscar um redimensionamento da posição do economista e industrial paulista Roberto Simonsen (1889-1948) na chamada controvérsia do planejamento econômico no Brasil, travada com Eugênio Gudin entre 1944 e 1945, este é, por exemplo, um aspecto importante a ser destacado logo de saída, expressando como de ambos os lados não existia uma presunção a priori da inutilidade do debate.

De fato, este debate pioneiro travado entre Roberto Simonsen e Eugênio Gudin oferece-se como um momento privilegiado para o estudo das ideias econômicas no contexto brasileiro, pelo motivo especial de que os dois pensadores, cada um ligado à economia por vias diferentes, empenharam-se na tarefa de debater diretamente questões econômicas, com o devido aprofundamento, mesmo que com enfoques teóricos bastante distintos, como comentaremos. Isto contribuiu para que a dita controvérsia do planejamento se convertesse em um dos temas de mais frequente citação em relação à história das ideias econômicas no Brasil e, como tal, bem 
estudado pela historiografia pertinente. Não obstante, acreditamos que existam ainda importantes questões a serem exploradas, em particular no que diz respeito à recomposição do quadro de influências teóricas que matizava as posições desses contendores, analisando este dado na confluência que se estabelece entre a análise da transmissão internacional das ideias econômicas e a definição das especificidades de uma história nacional do pensamento econômico, no sentido tratado por Cardoso (2003 e 2009).

Tendo em foco particularmente a contribuição de Simonsen ao debate, podemos dizer que não só existem dimensões ainda a merecer análise no que diz respeito ao quadro de influências no qual ele próprio transitou, mas também no que diz respeito à relevância de suas elaborações para se compreender o debate posterior relativo ao desenvolvimento. Sobretudo pela adoção de uma perspectiva histórica para tratar de problemas econômicos, a qual seria retomada pelo estruturalismo brasileiro, notadamente por Furtado, em Formação econômica do Brasil, de 1959. O uso por Celso Furtado de História econômica do Brasil, que Simonsen havia publicado em 1937, como fonte direta na elaboração de Formação é, por exemplo, um dado importante neste particular. De forma ampla, podemos já introduzir aqui que entender com maior propriedade a natureza teórica da argumentação de Simonsen na controvérsia do planejamento ajuda a mensurar a importância deste autor para consolidar e legitimar no Brasil um discurso que associava o desenvolvimento da nação à industrialização.

A historiografia sobre a vida e a obra de Roberto Simonsen vem merecendo contribuições significativas desde a década de 1960, sendo que vários desses textos são carregados de enaltecimentos à figura de Simonsen, devido a seu papel de líder industrial e a seu destaque político. Merecem destaque os seguintes estudos: Cepêda (2003), Fanganiello (1970) e Lima (1963 e 1976). Na perspectiva específica de história das ideias econômicas, o estudo que tratou da obra de Simonsen com algum grau de profundidade é o de Bielschowsky (2000), cuja análise da obra de Simonsen será desdobrada mais adiante.

A IMPORTÂNCIA DO CONTEXTO HISTÓRICO E DA DIFUSÃO INTERNACIONAL DE IDEIAS

A possibilidade de enriquecer a leitura das contribuições de Roberto Simonsen à controvérsia do planejamento se abre com a adoção de uma perspectiva metodológica que privilegie a dimensão histórica das ideias econômicas. Para captar a inserção específica de Simonsen na discussão, pela via da história econômica e da preocupação com o desenvolvimento brasileiro após a segunda guerra, há que se ter em conta os estudos reali- 
zados por Simonsen sobre a história do Brasil e o quadro de discussão em que estava inserido. Em outras palavras, cabe levar em conta a trajetória intelectual de Simonsen e as sintonias existentes entre a sua elaboração e as discussões contemporâneas.

Ainda que de maneira um tanto esquemática, é possível caracterizar duas linhagens de trabalho fundamentais às pesquisas na área de histórica do pensamento econômico. Por um lado, há um tipo de pesquisa mais voltada para a história da análise econômica, no sentido schumpeteriano de evolução da ciência em sentido estrito, sem levar em conta opiniões, interesses políticos e outros fatores não "analíticos" (Schumpeter, 1954, pp. 38-41). Por outro, existem uma investigações de caráter mais amplo, voltadas para o contexto histórico-social em que se dá a formulação de ideias. Blaug (1962) propõe a denominação "absolutista" para a primeira abordagem e "relativista" para a segunda. A vertente "absolutista" seria mais capaz de captar a lógica interna dos argumentos econômicos, dissociando os elementos ideológicos presentes nas diversas elaborações, de maneira a privilegiar o núcleo científico, supostamente relevante para a evolução do pensamento econômico, contido na formulação de cada autor. O historiador do pensamento econômico de viés "absolutista" sente-se à vontade para identificar os erros e limitações de uma teoria com base em sua visão presente. Por sua vez, os "relativistas" estariam interessados nas interações da história do pensamento econômico com a história intelectual, econômica, política e social. Nessa perspectiva, ideias não podem ser compreendidas dissociadas do seu tempo e das convicções extraeconômicas que informavam os seus autores. A visão de mundo filosófica, a ideologia, os interesses classe e vários outros determinantes históricos são vistos como poderosas influências atuantes sobre os economistas, em seu processo de criação de ideias.

No caso de um trabalho que se dedique a refletir sobre ideias econômicas que não estão claramente posicionadas dentro do cânone da evolução da economia enquanto disciplina, faz-se imprescindível uma reflexão que enverede, se não de todo, ao menos em parte pela segunda abordagem. A razão é simples. A formulação de ideias econômicas na América Latina anterior à década de 1950 não se dá com base num rigoroso debate conceitual e teórico. As elaborações de Simonsen, conforme se procurará mostrar neste trabalho, são marcadas por uma defesa da industrialização planejada, com base na caracterização histórica do atraso econômico e na apropriação de ideias econômicas internacionalmente difundidas. Por outro lado, é certo que pensadores liberais, como Eugênio Gudin, realizaram estudos formais em economia, mas isso não significa que sua principal contribuição intelectual tenha sido avançar, em sentido analítico, modelos preexistentes. O esforço de Gudin se refere à adaptação das formulações 
ortodoxas tradicionais à realidade brasileira, que o preocupava diretamente e sobre a qual era chamado a agir e a se posicionar.

É nesse sentido que este artigo parte de uma perspectiva relativista, que permite reconstituir historicamente o pensamento de Simonsen. A interpretação da história do Brasil, formulada por Simonsen, que enfatizava os ciclos econômicos coloniais e o caráter efêmero da riqueza gerada por eles, estava associada a uma crítica ao modelo primário-exportador e a uma defesa da industrialização, como processo que dotaria o Brasil de riquezas permanentes. Esse tipo de percepção se constrói a partir do entendimento do papel de Roberto Simonsen no contexto histórico em questão: seu projeto intelectual era ligado aos interesses da indústria.

O Brasil da era Vargas ou, mais amplamente, dos anos 1930 a 1960 é um país em fase de transição: de uma economia primário-exportadora para uma economia industrial capitalista. Essa ampla transição é a principal marca do contexto histórico em que se dá a controvérsia do planejamento, pois se trata de um momento de indefinição e criatividade: os rumos econômicos e políticos que prevaleceriam eram incertos, isto é, estavam em discussão as possíveis vias de desenvolvimento para o Brasil. O período mais específico em que se dá o debate é o final do Estado Novo, período no qual ganham preponderância, com relação aos governos provisório e constitucional de Getúlio Vargas, forças autoritárias e conservadoras, por vezes simpáticas ao fascismo (Diniz, 2004). Se há algum consenso de que, no período do Estado Novo, o governo Vargas inclinou-se para um projeto mais consciente de desenvolvimento econômico induzido pelo Estado, o sentido das políticas da administração getulista ao longo da década de 1930 tem suscitado debates na historiografia. Duas contribuições relevantes nesse sentido são: Fonseca (2003), que defende a intencionalidade industrializante das políticas governamentais nos anos 1930, e Bastos (2012), que vê o Estado Novo como inflexão nacionalista maior, sendo relativamente frágeis os indícios de nacionalismo econômico nas medidas tomadas pelo Estado varguista durante os governos provisório e constitucional.

Relevante para a compreensão da era Vargas como um todo é a ideia de que, com a Revolução de 1930, emerge um "Estado de compromisso". Este termo, utilizado por Boris Fausto (2010, pp. 136-144), refere-se ao arranjo institucional que emergiu no Brasil a partir de 1930: a situação de vácuo de hegemonia, em que as oligarquias dominantes perderam sua primazia no poder, sem haver outra classe que assumisse integralmente $o$ controle do Estado.

A controvérsia Simonsen-Gudin se deu no âmbito desse "Estado de compromisso" que, com vistas a planejar a economia, criou uma multiplicidade de órgãos públicos: foram criados o Departamento Nacional do Café (1933), o Conselho Federal de Comércio Exterior (1934), o Departamento 
Administrativo do Serviço Público (DASP) (1938), dentre vários outros órgãos reguladores e administrativos. Destacam-se aqui os dois órgãos mais diretamente envolvidos no debate Simonsen-Gudin, criados ainda no final do Estado Novo: a Comissão de Planejamento Econômico (CPE) e o Conselho Nacional de Política Industrial e Comercial (CNPIC), ambos de 1944.

A Comissão de Planejamento Econômico (CPE), da qual era membro Eugênio Gudin, era um órgão do Conselho de Segurança Nacional, que tinha como tarefa a elaboração de estudos gerais sobre economia brasileira e, em particular, de realizar estudos de interesse militar. A CPE deveria conceber a estrutura institucional que executaria o planejamento econômico. $\mathrm{O}$ Conselho, vinculado ao Ministério do Trabalho, Indústria e Comércio, era composto por representantes dos ministérios, das associações industriais e comerciais, de setores da burocracia econômica e de técnicos especialistas. Sua atribuição era o estabelecimento de princípios norteadores do desenvolvimento industrial brasileiro. Quando da criação do CNPIC, Roberto Simonsen, já participante do conselho consultivo da Coordenação de Mobilização Econômica (criada em 1942 para administrar a economia durante a guerra mundial), foi apontado como membro representante dos industriais.

É no âmbito do CNPIC que teve início a controvérsia que nos interessa aqui discutir. $\mathrm{O}$ órgão deveria tratar da questão de como o planejamento seria, de fato, institucionalizado no Brasil. Não havia, até então, um órgão que congregasse todas as esferas de planejamento econômico e que coordenasse, de forma sistemática, as ações do governo. Simonsen propunha que o próprio CNPIC se tornasse o órgão máximo do planejamento econômico no Brasil, diretamente subordinado à Presidência da República. A execução do plano seria levada a cabo por uma Junta de Planificação Econômica, formada por comissões de representantes das classes produtoras e de técnicos em economia, demografia e outras áreas.

A proposta de Simonsen, discutida no âmbito do Conselho, entretanto, não foi aprovada. Enviada anteriormente para a Comissão de Planejamento Econômico, suscitou o debate entre Roberto Simonsen e Eugênio Gudin. É instigante o fato de que o parecer de Roberto Simonsen tenha passado pela Comissão, mais especialmente pelas mãos de Gudin, renomado economista de inclinações liberais, que certamente se mostraria contrário às propostas de planificação e intervenção estatal. (Draibe, 1985; Von Doellinger, 2010).

Ao interpretar essa manobra que gerou o debate do planejamento, Draibe (1985) chama a atenção para os limites da autonomia de um Estado que, neste episódio, revela sua face frágil. Se é inegável que, desde meados dos anos 30, estavam presentes, na lógica da expansão do aparelho do Estado, os requerimentos de intervenção, planificação e aprofundamento dos controles econômicos, abrindo espaço para a ação industrializante, 
também é certo que, na conjugação de forças que sustentava esse Estado, encontravam-se fortes elementos contrários à industrialização, à nacionalização, à intervenção e ao planejamento.

Para captar outra dimensão importante da participação de Simonsen no debate -as sintonias com autores estrangeiros- incorpora-se à análise da controvérsia do planejamento a questão da transmissão internacional das ideias econômicas. $\mathrm{O}$ estudo desse tema pode ser profícuo em vários sentidos, para a construção do conhecimento em história do pensamento econômico. José Luís Cardoso (2009, p. 263) elenca três atributos principais que permeiam o estudo da difusão internacional das ideias. $\mathrm{O}$ primeiro seria o aprofundamento da compreensão dos autores apropriados internacionalmente: as leituras seletivas em países estrangeiros, os objetivos com os quais determinado autor é referido, a utilização de recomendações e receituários no campo da política econômica -tudo isso alarga o conhecimento sobre o autor apropriado. Em segundo lugar, o estudo da difusão de ideias permite rever ou esclarecer melhor a relação entre precursores e antecipadores, relativizando auras de pioneiros ou inventores e permitindo que se identifiquem ambientes favoráveis a que certas ideias vicejem. O terceiro atributo é relacionado à possibilidade de melhor aquilatar a importância e impacto de escolas heterodoxas no país receptor, relativizando esquemas, por vezes muito rígidos, de arrumação e classificação de autores. Todos esses atributos da abordagem de difusão das ideias podem ser entendidos como meios de se construir uma história nacional do pensamento econômico, o que, no caso, tem pertinência direta para o tipo de análise aqui dedicada à contribuição de Simonsen e sua relação com um panorama mais amplo das ideias econômicas de seu tempo.

\section{IDEIAS ECONÔMICAS NO BRASIL E NA AMÉRICA LATINA}

O pensamento econômico latino-americano do início do século Xx, especialmente no que se refere ao comércio internacional e o desenvolvimento, é marcado pela prevalência das teses relacionadas às vantagens comparativas. Love (1995) considera que parecia haver uma correspondência entre bom desempenho econômico, dinamismo do setor exportador e a teoria das vantagens comparativas, de forma que a especialização da América Latina na produção de matérias-primas estava justificada. A vigência da concepção ricardiana convivia com a defesa, de caráter classista e por vezes nacionalista, de políticas cambiais e fiscais favoráveis à indústria. Tal defesa, feita sobretudo por industriais e políticos, é marcada pela ausência de projeto teórico e ideológico consistente (Luz, 1975). Procura-se mostrar que a controvérsia do planejamento se diferencia destas formulações do 
início do século Xx e que a elaboração de Simonsen, em particular, é uma defesa mais consistente e bem fundamentada da industrialização brasileira, embasada na história econômica e em sintonia com as discussões internacionais do final da segunda guerra.

Sem menosprezar a importância, para a defesa do projeto industrialista, de autores como Vieira Souto e Serzedelo Correia, pretende-se frisar que, na América Latina, as formulações teóricas, no campo da economia, alternativas à ideia ricardiana das vantagens comparativas estão longe de ser um pensamento coeso e muito menos dominante (Luz, 1975). No caso brasileiro, essa situação era mais clara, no sentido de que nem mesmo a economia como disciplina acadêmica estava estabelecida até 1937, quando é fundada, por Gudin e outros interessados, a Sociedade Brasileira de Economia Política, sediada no Rio de Janeiro, com vistas à criação de um estabelecimento de ensino da disciplina no Brasil. A Faculdade de Ciências Econômicas e Administrativas ${ }^{1}$ é criada no ano seguinte, tendo Eugênio Gudin à frente da cátedra de moeda e crédito (Keller, 2001).

Bielschowsky (2000) considera a Fundação Getúlio Vargas (FGV), criada em 1944, o primeiro fórum relevante de discussão do pensamento econômico brasileiro de matriz liberal. Conforme informa Dias (2001), Roberto Simonsen participou da fundação, em 1932, da Escola Livre de Sociologia e Política, ${ }^{2}$ onde foi professor da cadeira de história econômica do Brasil. Embora pioneiro em São Paulo e no Brasil, não se trata de um centro de discussão especialmente voltado aos problemas econômicos, o que não impediu que, a partir de sua atividade docente, Simonsen desenvolvesse o estudo pioneiro História econômica do Brasil, que publica em 1937. O livro de Eugênio Gudin, Princípios de economia monetária, entre os primeiros livros-texto de economia publicado no Brasil, foi lançado em 1943, sendo reeditado diversas vezes.

Já se fez menção aos diversos órgãos públicos que foram criados, principalmente a partir do Estado Novo, nos quais se discutia, com grau de formalidade e rigor variável, ideias econômicas relacionadas ao desenvolvimento do Brasil. No setor privado, também se formaram fóruns de discussão e difusão de ideias econômicas. Dois anos antes de seu falecimento, em 1948, Simonsen instituíra, na Confederação Nacional da Indústria (CNI), o Conselho Econômico e o Departamento Econômico, que foram núcleos importantes na discussão sobre o desenvolvimento brasileiro (Lima, 1976).

\footnotetext{
${ }^{1}$ A Faculdade de Ciências Econômicas e Administrativas foi posteriormente incorporada à Universidade do Brasil, hoje Universidade Federal do Rio de Janeiro.

${ }^{2}$ A Escola Livre de Sociologia e Política existe até hoje, sob o nome de Fundação Escola de Sociologia e Política de São Paulo, como instituição privada de ensino superior. É considerada um centro pioneiro no ensino e pesquisa em ciências sociais no Brasil, tendo formado pensadores como Darcy Ribeiro e Florestan Fernandes.
} 
Entre 1950 e 1954, o Departamento Econômico da CNI editou a revista Estudos Econômicos, que publicou dois trabalhos pioneiros de Prebisch na Comissão Econômica para a América Latina (CEPAL), cumprindo papel importante no processo de difusão das ideias econômicas no Brasil.

Bielschowsky (2000, p. 258) afirma que, até meados da década de 1940, não se gerou, no Brasil, um projeto de industrialização articulado e bem definido, por mais que houvesse uma ideologia industrialista em formação, entre as equipes administrativas e técnicas da burocracia estatal. Sua leitura da obra de Simonsen encaixa-se nessa chave interpretativa: "Simonsen não viveu a fértil década de elaboração da chamada 'economia do subdesenvolvimento', que se seguiu à segunda guerra mundial e que trouxe para a América Latina a resposta analítica da CEPAL às proposições teóricas e práticas do liberalismo econômico. Seu pensamento pairou, por isso, sobre um vazio teórico [...]" (Bielschowsky, 2000, p. 87). Essa argumentação tem um elemento de anacronismo, pois avalia a elaboração de Simonsen a partir da resposta analítica cepalina, que viria a ser formulada quase duas décadas depois. Nesse sentido, esse tipo de raciocínio contribui pouco para o estudo da especificidade do pensamento de Simonsen: os textos da controvérsia do planejamento mostram que havia, sim, da parte de Simonsen, uma busca por referências teóricas, sem que houvesse a adesão a uma escola de pensamento única.

A importância da contribuição de Simonsen se refere mais ao seu tipo de abordagem do problema do desenvolvimento, relacionada à história e ao planejamento, do que à formulação e discussão de teorias econômicas, o que não torna sua contribuição alheia à discussão econômica, pelo contrário. Há relações e sintonias inegáveis entre Simonsen e o debate econômico. As ideias de Manoilescu e List, por exemplo, são reconhecidamente apropriadas por industrialistas latino-americanos, inclusive Roberto Simonsen. Carl Landauer, economista alemão radicado nos Estados Unidos e professor de Berkeley, Califórnia, é citado por Simonsen, em sua resposta a Gudin. Landauer publicara, em 1944, Theory of national economic planning, livro em que fez uma defesa coerente do planejamento econômico. A apropriação de Landauer por Simonsen é um caso raro em que a sintonia ficou evidente não só a partir da citação e da afinidade de conteúdo, mas também a partir de indícios ainda mais concretos: o livro de 1944 pertence à Coleção Roberto Simonsen e contém anotações e sublinhados que permitem visualizar a leitura feita por Simonsen e a apropriação das ideias no texto de resposta a Gudin, redigido em $1945 .^{3}$

${ }^{3}$ A Coleção Roberto Simonsen é resultante de uma doação da Federação da Indústrias do Estado de São Paulo (FIESP) à Universidade Estadual de Campinas. A coleção possui, entre vários volumes que integravam o acervo da FIESP, livros que pertenceram a Roberto Simonsen. 
Vale lembrar que há, com o desenrolar do conflito mundial na década de 1940, alguns sinais na direção da incorporação de propostas teóricas e ideológicas ligadas ao atraso econômico e à industrialização de países atrasados, por parte de alguns economistas e organismos como a Liga das Nações, historicamente pró-liberalismo (Love, 1995, p. 402). Certamente, a controvérsia pioneira brasileira -e a elaboração de Simonsen em particular- estava em sintonia com as ideias progressistas que começavam a circular àquele tempo.

Na década de 1950, dois projetos políticos -o desenvolvimentista e o liberal (Bielschowsky, 2000, p. 7) $-^{4}$ estariam mais claramente definidos no Brasil. A criação da Comissão Econômica para a América Latina pela Organização das Nações Unidas será importante para que Prebisch e, no caso do Brasil, Furtado formulem teorias inovadoras que embasem a defesa da industrialização num contexto periférico. Num momento próximo, porém anterior à criação de uma identidade cultural e econômica para o subcontinente latino-americano, Simonsen buscou respostas originais para as questões com as quais se defrontou, a partir de ideias difundidas internacionalmente e do estudo da história econômica do Brasil.

\section{A originalidade DaS ElaboraÇÕes de Roberto Simonsen}

Uma leitura mais superficial dos documentos que constituem a controvérsia do planejamento pode deixar a impressão de que Simonsen não está tão bem armado quanto Gudin para a discussão econômica. De fato, o autor não parece dominar as tecnicalidades econômicas que Gudin utiliza em sua argumentação. Nesse sentido, a elaboração de Gudin parece mais sofisticada e coerente, enquanto as ideias de Simonsen parecem ter caráter propositivo, com pouca complexidade teórica e argumentativa. Todavia, essa ideia perde força quando se tem em conta que a entrada de Simonsen no debate se dá por um caminho distinto daquele percorrido por Gudin: é uma incursão pela via da história econômica. Para entender a forma como Simonsen entra nessa discussão, convém destacar alguns pontos relevantes da sua obra e das suas ideias: em especial, destaca-se a introdução de uma perspectiva histórica no estudo da economia brasileira.

Talvez o principal contributo de Simonsen como pensador da realidade brasileira seja sua História econômica do Brasil, obra fundante na historiogra-

\footnotetext{
${ }^{4}$ Entende-se por desenvolvimentista o projeto político ligado à ideia de que o Brasil deveria passar por um processo de transformação social com base na industrialização integral e planejada pelo Estado. O projeto liberal se refere, em suma, à oposição ao desenvolvimentismo, baseada na ideia de que a superação dos problemas brasileiros não passaria pela transgressão dos princípios do livre-mercado.
} 
fia econômica do país e grande contribuição ao pensamento social brasileiro em geral. ${ }^{5}$ Trata-se de um estudo detalhado sobre o Brasil-Colônia, isto é, sobre a formação da economia brasileira, do descobrimento à independência. $\mathrm{O}$ autor entende que é esse o período em que "se formou a trama social asseguradora da estrutura unitária do país” (Simonsen, 1969, p. 25).

A obra de Simonsen é alvo de críticas por dar à história econômica brasileira uma interpretação muito restrita aos ciclos. ${ }^{6}$ É uma abordagem que privilegia, para cada fase da história econômica, um produto-rei, geralmente primário, em torno do qual toda a economia e a sociedade se organizam. Todavia, vale notar, com Flávio Saes (2009), que aquilo que está implícito na abordagem dos ciclos é coerente com o projeto de $\mathrm{Si}$ monsen e lança as bases para interpretações posteriores: o fato de que a economia colonial era dominada por fases de expansão pronunciada da riqueza, seguidas por momentos de dilapidação rápida da mesma, implica que esta economia primário-exportadora nada legava de permanente à nação. Somente a industrialização poderia de fato possibilitar a "evolução progressista" do Brasil. Portanto, se, por um lado, é excessivamente esquemática, a interpretação de Simonsen não é incoerente com seu projeto político e intelectual e suas implicações têm profunda importância para as discussões posteriores acerca da história econômica do Brasil.

A tarefa de que está imbuído o livro é, para Simonsen, a construção da consciência nacional, que seria fundamental para o progresso do país. Trata-se de compreender o atraso, constatado na realidade, por meio do estudo da história econômica, sempre com vistas à superação das mazelas brasileiras. Nesse sentido, a obra integra o projeto político de Simonsen, não como defesa explícita -ou teórica- da industrialização, mas como subsídio para o entendimento dos problemas presentes, com vistas a superá-los. Simonsen busca, na colonização, respostas para as perguntas que se lhe colocavam: por que o Brasil não tinha os mesmos níveis de desenvolvimento industrial do que os Estados Unidos? A resposta, em alguma medida, residia no caráter cíclico, isto é, pouco durável, da riqueza gerada pela economia colonial, exportadora de bens primários. "Procuraremos determinar, pela evolução comparativa entre os povos, a razão do atraso de nossas atividades econômicas em determinadas épocas e para determinadas regiões. [...]. Esforçar-nos-emos, enfim, por indagar a origem dos muitos entraves que dificultaram e dificultam, a nossa evolução progressista" (Simonsen, 1969, p. 24).

\footnotetext{
${ }^{5}$ O objetivo do livro era prover material de estudo para a cadeira de História Econômica do Brasil, instituída na Escola Livre de Sociologia e Política de São Paulo.

${ }^{6}$ Essa concepção é baseada no clássico português Épocas de Portugal econômico, de João Lúcio de Azevedo.
} 
O principal aporte de Simonsen não é a formulação de ideias "estritamente" econômicas novas, que resolvam alguma questão analítica de forma sofisticada. Sua principal contribuição é a introdução de uma compreensão do problema econômico brasileiro a partir de uma perspectiva histórica. É necessário escrever uma história econômica do Brasil para que se possa entender a situação atual da economia brasileira: é esta a lacuna fundamental que seu livro tenta preencher. O ponto de partida de Simonsen é a história, pois sem a história não seria possível entender a especificidade da economia brasileira: sua inserção internacional, sua dependência e seu grau de atraso.

A entrada de Simonsen no debate econômico pela via da história possui afinidades importantes com o projeto intelectual e metodológico da Escola Histórica Alemã, que teve em Friedrich List seu precursor. Vale lembrar, com Boianovsky (2011, p. 4), a importância da exposição de List ao debate norte-americano sobre protecionismo, iniciado por Alexander Hamilton no final do século XVIII, para a construção de sua concepção de economia, baseada na ideia de nação. ${ }^{7}$ Para os pensadores ligados a à corrente historicista, que foi muito influente no mundo germânico da segunda metade do século XIX, o conhecimento em economia deveria emanar da história, isto é, a partir de estudos históricos sobre contextos específicos, construía-se a ciência econômica. Justamente por ser baseado na pesquisa histórica monográfica, esse conhecimento não almejava a formulação de leis universais, mas, sim, explicações para a evolução de uma realidade econômica que, o mais das vezes, é referida a um contexto nacional. A unificação e o fortalecimento da nação eram questões prementes na Alemanha do século XIX e, dessa forma, a "alma nacional", no dizer de Schumpeter (1954, pp. 422-423), foi alvo de reflexão em vários campos intelectuais, como a literatura, o direito e a economia. A agenda política de reforma social, aliada à recusa tanto do "liberalismo de Manchester", quanto do marxismo era outro ponto de afinidade entre Simonsen e os historicistas alemães.

Para além de Friedrich List, citado no debate Simonsen-Gudin e por vários outros autores ligados ao protecionismo no Brasil desde as últimas décadas do Oitocentos, dois pensadores, mais diretamente ligados à Escola Histórica e ao Verein für Sozialpolitik (Sociedade para a Política Social), estavam presentes em textos de Simonsen anteriores à controvérsia do planejamento. Essa presença permite afirmar que havia, da parte do autor,

${ }^{7}$ As ideias de Hamilton sobre o papel das manufaturas na economia e sobre a política de proteção a ser adotada pelos Estados Unidos estão no documento conhecido como Report on Manufactures, um comunicado de Alexander Hamilton, então secretário do Tesouro, à Câmara dos Representantes, em 5 de dezembro de 1791. 
uma apropriação das ideias ligadas a essa linhagem alemã de pensamento, que deu especial ênfase ao ordenamento estatal (Tribe, 2009) e, no último quartel do século XIX, ao protecionismo (Hagemann, 2001). Em 1935, durante os debates parlamentares em torno da ratificação do Tratado Comercial Brasil-Estados Unidos, Simonsen fez uma referência muito positiva ao conceito de "economia nacional", formulado por Adolph Wagner (18351917), em seu Grundlegung der politischen Ökonomie (Fundamentos de economia política, publicado em 1876), livro que circulou no Brasil em sua edição francesa. Na História econômica do Brasil, de 1937, Simonsen recorreu a Gustav Schmoller (1838-1917), talvez o mais proeminente economista da Escola Histórica, para discutir temas como o caráter capitalista ou feudal das capitanias hereditárias e o sentido do trabalho livre, na Europa e no Brasil. O livro de Schmoller, que também circulou no Brasil em francês e onde se encontram essas discussões referidas por Simonsen, é Grundriss der Volkswirtschaftslehre (Princípios de economia política, publicado entre 1900 e 1904).

Vale lembrar a importância dessa perspectiva histórica para a compreensão do desenvolvimento brasileiro -e para a formulação posterior de proposições teóricas alternativas, na América Latina. A contribuição teórica trazida por Celso Furtado, por exemplo, foi possível a partir da caracterização do subdesenvolvimento como produto de uma evolução histórica específica. Em Formação econômica do Brasil, que é justamente uma tentativa de interpretar o evolver histórico da economia brasileira, Furtado beneficiou-se largamente da História econômica de Simonsen, que é um dos únicos pensadores brasileiros explicitamente referenciados por Furtado em seu clássico. Simonsen inaugura no Brasil, portanto, uma maneira de abordar o problema do desenvolvimento econômico numa perspectiva histórica, que será relevante para a consolidação do método histórico-estruturalista, que se firmaria, já na década de 1950, como alternativa, no âmbito do pensamento econômico latino-americano, às ideias liberais. Existiam ideias econômicas em circulação, segundo as quais as "vantagens comparativas" do Brasil deveriam ser aproveitadas. A realidade, contudo, correspondia a um país que, embora maior produtor mundial de café, era dependente, incapaz de proporcionar um nível de vida razoável aos seus cidadãos e possuidor de estrutura industrial incompleta e relativamente débil. Essa situação deveria ser superada.

A superação dessa debilidade era, ao menos no caso do Brasil, a industrialização planejada, que também era vista numa perspectiva histórica e comparativa: países que se industrializaram lograram atingir níveis elevados de progresso econômico. Simonsen, para além de um estudioso, era um industrial e porta-voz dos interesses de classe da indústria: era ele mesmo um industrial e presidente da Federação das Indústrias do Estado 
de São Paulo (1938-1946). O Brasil, portanto, deveria seguir esta rota: a industrialização era vista como a maneira de superar a pobreza e o atraso brasileiros. Simonsen preconizava uma industrialização integrada, que abrangesse até a indústria de base. "As maiores verbas da planificação seriam, sem dúvida, utilizadas nas eletrificações do país, na mobilização de suas várias fontes de combustíveis e na organização de seus equipamentos de transportes. Seriam criadas indústrias-chave, metalúrgicas e químicas, capazes de garantir uma relativa autossuficiência ao nosso parque industrial e sua necessária sobrevivência na competição internacional" (Simonsen, 2010a, p. 45).

O sucesso do projeto industrializante só se daria, para Simonsen, com o apoio de decisiva intervenção governamental, que deveria se materializar por meio dos instrumentos de política econômica adequados: o planejamento e o protecionismo aduaneiro. Boianovsky (2011, p. 3) destaca um ponto relevante sobre o pensamento protecionista de List e a sua recepção no Brasil e na América Latina, por Simonsen e outros industrialistas. Os argumentos protecionistas listianos teriam sido pensados para industrializações retardatárias de países hoje centrais, a exemplo da Alemanha, mas não para países tropicais, haja vista que List divide o mundo entre zonas "tropicais" ou "tórridas" e zonas "temperadas", devendo somente as últimas seguir a rota da industrialização. Boianovsky (2011, p. 32) sugere que os economistas latino-americanos do final do século XIX e primeira metade do XX teriam feito uma leitura seletiva de List, destacando os argumentos que lhes interessavam e deixando de lado ideias como a da divisão "climática" do mundo. Esse seria o caso de Simonsen, com seus argumentos de que a independência política e econômica das nações só seria alcançada na medida em que a indústria fosse protegida, acompanhando o desenvolvimento da agricultura.

Simonsen não citou diretamente List em seu debate com Gudin, mas apresentou, como observa Boianovsky (2011, p. 26), argumentos afins às ideias listianas, como, por exemplo: "As tarifas protecionistas adotadas por mais de 120 anos nos Estados Unidos nada mais foram do que um instrumento de planejamento [...], transformando-o de país agrícola em potência mundial" (Simonsen, 2010b, p. 155). Como Boianovsky (2011, p. 27) indica mais adiante, é Gudin (2010a, p. 99) quem citou diretamente List, justamente para lembrar o caráter temporário e moderado das medidas protecionistas que o autor alemão defendia para a indústria infante. Também é Gudin (2010a, pp. 100-102) que cita, no debate de 1944-1945, o autor romeno Mihail Manoilescu, com o objetivo de desconstruir os seus argumentos protecionistas.

Conforme Rodrigues (2005, p. 63), Manoilescu pretendia preencher a lacuna relativa à ausência de uma teoria "científica" do protecionismo. 
Não só o livre-cambismo de matriz clássica, mas também as ideias protecionistas de List são criticadas por Manoilescu, por supostamente se situarem num terreno "alheio ao econômico". O argumento central do economista romeno é que não é a produtividade relativa (ou os preços relativos, vistos como reflexo da produtividade) que deve ser levada em conta ao se mensurar as vantagens do comércio internacional, mas, sim, a produtividade absoluta. Qualquer atividade que eleva a produtividade média do país deve ser instalada, sendo irrelevante a comparação com o estrangeiro. Importa, sobretudo, elevar a produtividade média do país. Usando o exemplo clássico de Ricardo, Manoilescu insiste que pouco importa que a indústria têxtil da Inglaterra seja mais produtiva que a de Portugal: o resultado teórico é que os dois devem se especializar em panos, pois a indústria em um determinado país é, via de regra, mais produtiva do que a agricultura neste mesmo país (obtém-se mais produto por unidade de trabalho ou capital empregado). Para se tornar mais produtivo, portanto, e auferir maior lucro nacional um país deve se industrializar cada vez mais, transferindo recursos da agricultura, setor pouco produtivo, para a indústria, setor mais produtivo, ainda que para isso tenha de proteger os setores industriais novos, menos competitivos do que a indústria estrangeira. À indagação sobre a possibilidade de importar produtos industriais a custos menores, já que a indústria estrangeira é mais produtiva, Manoilescu responde com a ideia de mercadoria de permuta. Para importar algo, um país deve dar em troca (ou vender para obter divisas) mercadorias de permuta, as quais, geralmente, são produzidas em condições menos sofisticadas, ou menos produtivas, do que aquelas em que se produz a mercadoria importada. A proteção, portanto, se justifica sempre que o setor que se deseja instalar operar com produtividade mais elevada do que os setores nos quais são produzidas as mercadorias de permuta, usadas na importação. Isso garante que se eleve a produtividade média da nação e, por conseguinte, seu lucro nacional (Manoilescu, 2011).

Simonsen parece ter sido atraído pelo caráter científico das teorias de Manoilescu, tendo patrocinado, por meio do Centro das Indústrias de São Paulo (CIESP), a edição brasileira de seu livro Teoria do protecionismo e da permuta internacional (1931). Contudo, já no momento da controvérsia do planejamento, Simonsen não cita o autor romeno. Um possível motivo para isso são as simpatias pelo fascismo presentes em livro posterior de Manoilescu, publicado no Brasil em 1938: O século do corporativismo. Não é inadvertidamente que Gudin discute com Manoilescu em sua resposta a Simonsen: a associação entre planejamento e autoritarismo/totalitarismo era feita por Gudin, no intuito de desqualificar a defesa da planificação econômica.

Um importante legado de Simonsen às gerações futuras de economistas foi a defesa do planejamento, que procurou associar à democracia e à 
manutenção da propriedade privada, resguardando-se de argumentos que associavam planificação econômica e socialismo. Chamava atenção, ainda durante o desfecho da segunda guerra, para a necessária adaptação da estrutura montada para planejar a guerra à situação de paz que se anunciava. "A Rússia soviética fará, com maior facilidade que outras nações, a transição da economia de guerra para a da paz, não porque tenha um governo ditatorial, ou porque todas as suas indústrias são propriedade do Estado, mas em virtude de sua maior experiência no planejamento econômico" (Simonsen, 2010b, p. 133).

Simonsen acreditava que a intervenção estatal deveria ir além das formas indiretas de atuação, devendo o Estado tomar a iniciativa de fazer investimentos diretos em setores nos quais a iniciativa privada não se fizesse presente. A intervenção do Estado era um desdobramento da própria ideia de planificação econômica, devendo abranger os investimentos na indústria de base, na educação, na pesquisa e em outras áreas consideradas estratégicas.

Percebe-se que o tipo de preocupação de Roberto Simonsen condiciona a sua forma de incursão no debate com Eugênio Gudin. A sua preocupação passava pela defesa do setor em que atuava e que representava -a indústria- e também pela construção de uma consciência nacional a respeito do atraso econômico, com vistas a superá-lo. Essa conscientização só seria obtida por meio do estudo da evolução histórica da economia brasileira. Na próxima seção, veremos com mais detalhe a especificidade da abordagem histórica de Simonsen, no âmbito da controvérsia do planejamento.

\section{AS PERSPECTIVAS NO DEBATE E AS PROPOSTAS PARA O BRASIL}

Foi destacado que a controvérsia do planejamento se distingue dos debates brasileiros sobre industrialização na primeira metade do século Xx, por conter uma discussão mais consistente relacionada ao desenvolvimento brasileiro. Além disso, mostrou-se que Simonsen entra na discussão a partir de preocupações relacionadas com a industrialização e a história econômica do Brasil, introduzindo, no debate sobre o planejamento, uma perspectiva histórica sobre o problema do atraso. Destaca-se agora como essa especificidade aparece no âmbito da controvérsia com Gudin. Comparam-se, nesta seção, as abordagens de Eugênio Gudin e Roberto Simonsen para o problema econômico brasileiro, para mostrar a especificidade da argumentação de Simonsen e o grau de sintonia desta com as discussões que emergem a partir do fim da segunda guerra.

Para capturar essa sintonia das elaborações de Simonsen com o debate do final da segunda guerra, destaca-se e o já mencionado economista Carl 
Landauer (1891-1983). Em Berkeley, onde se tornou professor, publicou o livro que Simonsen utilizou no intuito de legitimar suas propostas relacionadas ao planejamento. Exilado do principal país beligerante, Landauer é profundamente marcado pelo contexto da segunda guerra, em que é chamado a posicionar-se sobre a questão do rumo que as economias mundiais tomariam a partir do desfecho dramático da "era da catástrofe". O papel de Carl Landauer como professor em Berkeley é discutido por Grossman, Grether y Letiche (1985). Simonsen faz sua discussão em sintonia com esse quadro geral de preocupações do final da guerra. No caso de Landauer, como já foi referido, a apropriação feita por Simonsen foi direta e consciente: o livro de Landauer foi anotado por Simonsen, em passagens que foram reproduzidas e adaptadas, na controvérsia do planejamento.

\section{A posição de Eugênio Gudin}

Passemos brevemente pela análise feita por Eugênio Gudin sobre os problemas econômicos do Brasil, em seus pareceres para a controvérsia do planejamento, para, então, apresentar a visão de Simonsen, em perspectiva comparada. Podem-se identificar considerações de Gudin acerca dos processos que teriam levado à conjuntura que observava nos anos 1940 espalhadas em seu livro-texto (Gudin, 1956) e em suas duas contribuições ao debate com Simonsen (Gudin, 2010a e 2010b). Em seus Princípios de economia monetária, Gudin reconhecia que as economias atrasadas possuíam especificidades com relação às desenvolvidas. "A doutrina clássica presumia uma relativa igualdade entre as economias dos países em apreço, quando, na realidade, do ponto de vista internacional, umas são muito mais vulneráveis do que outras: maior ou menor grau de internacionalidade, dependência, ou não de poucos produtos de exportação, procura elástica ou inelástica das exportações e importações, etc.” (Gudin, 1956, p. 272).

Por causa dessas especificidades, o mecanismo automático de ajuste no balanço de pagamentos, que operaria no padrão-ouro, não funcionaria perfeitamente, sendo necessário aplicar políticas cambiais, tarifárias ou de controle quantitativo de importações: as políticas cambiais seriam preferíveis às tarifas alfandegárias que seriam, por sua vez, preferíveis às licenças para importações, vistas por Gudin como uma intervenção excessiva do Estado, que poderia auferir para si benefícios do comércio exterior.

No caso específico do Brasil, Gudin postulava que a economia nacional estaria em pleno emprego e qualquer política industrializante tenderia a roubar fatores da agricultura, promovendo inflação e reduzindo a eficiência do sistema econômico. A posição de Gudin sobre a indústria e seu papel no desenvolvimento era baseada na ideia de que a economia 
brasileira sofria de baixa produtividade e pleno emprego (e não de especialização primária e desemprego) e de que indústria de baixa produtividade não é sinônimo de prosperidade (Bielschowsky, 2000, pp. 55-56). O relevante seria aumentar a produtividade da agricultura, partindo-se para a implantação da indústria leve, à medida que a agricultura liberasse mão de obra, sendo a industrialização pesada relegada a um horizonte remoto. "Precisamos é aumentar nossa produtividade agrícola, em vez de menosprezar a única atividade econômica em que demonstramos capacidade para produzir vantajosamente" (Gudin, 2010a, p. 106).

Eugênio Gudin percebia as especificidades das economias atrasadas, ou mais vulneráveis, mas essas diferenças com relação ao mundo desenvolvido não eram vistas como historicamente construídas. A superação do atraso não passaria, portanto, por um processo industrialização planejada que determinasse novos rumos para o país, mas, sim, pelo aumento de produtividade em alguns setores-chave. Em sua primeira resposta a Simonsen, Gudin abordou o tema, ao tentar desconstruir a "mística do plano". No intuito de destacar o caráter "anacrônico" da planificação e suas desvantagens em relação ao livre mercado, Gudin comparava o mercantilismo, que exigia boa dose de planificação e intervenção estatal, à economia liberal, baseada no interesse dos indivíduos.

A doutrina do laissez-faire, a cujo impacto rapidamente ruiu o sistema mercantilista, baseava-se, ao contrário, no princípio de que a riqueza de uma nação é a integral da riqueza de seus cidadãos; de que o indivíduo, guiado pelo interesse próprio, procura empregar seu trabalho e seu capital de modo mais proveitoso para sua economia e, portanto, de que o meio mais rápido e mais seguro de enriquecer a nação é o de deixar aos indivíduos plena liberdade de ação econômica (Gudin, [1945] 2010a, p. 65).

A economia liberal, com suas evidentes vantagens com relação ao sistema planificado mercantilista, ter-se-ia firmado como forma de organização da economia a partir do declínio do mercantilismo. Ao Estado, era reservado um papel limitado na economia liberal: "O Estado devia impedir que a liberdade fosse utilizada para matar a liberdade" (Gudin, 2010a, p. 65). Deveria regular, sem diretamente controlar, instrumentos de progresso como o gás de iluminação pública, os transportes (ferroviários), o serviço telegráfico, etc. Economia liberal parece ser, para Gudin, um sistema econômico -uma realidade- à qual corresponderia uma doutrina econômica específica. A economia liberal seria, pois, um período em que vigorara um consenso de princípios liberais, que orientavam o comportamento das economias nacionais, de modo a proporcionar à humanidade o maior nível de conforto material e de liberdade até então visto. O período 
de economia liberal se encerraria com a primeira guerra. "Até 1914 a economia liberal conduziu a humanidade por essa rota, de constante aumento de bem-estar e de elevação do padrão de vida das populações. Dentro dos seus padrões se abordavam e resolviam os novos problemas à medida que eles surgiam. [...]. No campo internacional o bastão da liderança cabia à Inglaterra, que velava pelo equilíbrio do sistema" (Gudin, 2010a, p. 66).

O período da dita economia liberal corresponderia, grosso modo, ao período da pax britannica, em que vigorara, no mundo ocidental, uma relativa estabilidade, ditada pela força da potência hegemônica. Os alicerces dessa ordem mundial britânica são abalados com a primeira grande guerra, que teria desorganizado os sistemas monetários das nações, até atingir a libra esterlina e o dólar. A guerra teria, ainda, precipitado um caos político e econômico na Europa, do qual emergiram "revoluções sociais" na Rússia e, depois, na Itália e Alemanha. Também nesse processo, ocorreria o deslocamento da hegemonia mundial, nas palavras de Gudin, "das mãos experimentadas da Inglaterra, para as mãos vigorosas, mas ainda inexperientes, dos Estados Unidos" (Gudin, 2010a, p. 66).

A Grande Depressão subsequente seria um resultado dos erros da nova potência hegemônica, ainda inexperiente para reger o mundo. Gudin (2010a, p. 67) citou textos do Departamento de Comércio norte-americano, no intuito de confirmar suas teses sobre as crises econômicas do século XX. A crise de 1920-1921 teria sido causada, nos EUA e em outros países, pelo movimento inflacionista resultante do abandono dos controles e restrições adotados ao longo da primeira guerra. Como causas da Grande Depressão dos anos 1930, elencava a política creditícia contracionista adotada pelo Federal Reserve em momento inadequado e a política aduaneira protecionista dos Estados Unidos, que teriam levado a uma escassez no suprimento internacional de dólares, numa hora em que este era por demais necessário. A Inglaterra, potência já não mais hegemônica, mas relevante, não era poupada por Gudin: também teria errado ao firmar uma política deflacionista, a partir de 1925 , com o fito de restabelecer a paridade da libra com o dólar.

A conclusão dessa análise retrospectiva é que os diversos desacertos, sobretudo políticos, teriam abalado os alicerces da economia liberal, a qual -assim parece- teria conduzido o mundo por um caminho estável de prosperidade, não fossem essas injunções de caráter extra-econômico. "Não cabe assim à economia liberal a responsabilidade desses desastres. Originariamente, a Grande Depressão foi o resultado de um fenômeno político: a guerra mundial de 1914, que abalou profundamente o sistema que a economia liberal havia construído em um século" (Gudin, 2010a, p. 69).

Os mecanismos de livre-mercado ofereceriam uma situação de prosperidade, no geral, à humanidade, a menos que houvesse a interveniência 
de fatores exógenos, que pudessem desequilibrar o sistema. Gudin critica acerbamente o new deal americano, que considera falho em vários pontos e incompatível com a economia liberal e com o respeito ao capital. "De certo, só tinha o New Deal o princípio da execução de obras públicas pelo Estado como um dos meios de contrabalançar a depressão [...] e algumas justas medidas de policiamento contra abusos do capitalismo" (Gudin, 2010a, p. 71). Embora concordasse com as medidas preconizadas por Keynes (e previstas no new deal) de combate a depressões cíclicas, Gudin no geral considera o plano de Roosevelt um erro que teria levado os EUA a se recuperarem da crise mais lentamente do que outras nações. A percepção retrospectiva de Gudin era, nesse sentido, um diagnóstico muito mais da conjuntura econômica em si, do que dos determinantes históricos que levaram à situação presente. Para Eugênio Gudin, cumpria explicar por que razões a conjuntura se distanciava daquela trajetória estável, que, ceteris paribus, a economia mundial seguiria, caso prevalecessem os princípios da economia liberal.

Essa posição de eximir a economia de qualquer "culpa" relacionada às mazelas da realidade concreta parece herdeira da mudança de ênfase ocorrida na economia, em finais do século XIX, com a revolução marginalista e o triunfo da concepção neoclássica. $\mathrm{O}$ enfoque da economia passa a ser os problemas de equilíbrio alocativo e não mais as questões de crescimento, desenvolvimento e reprodução, que haviam preocupado os clássicos. Analisando as relações dessa mudança de ênfase com questões ideológicas, Deane (1980) ressalta que essa diminuição do raio de alcance da economia permitia aos economistas aderir a uma certa ideologia em bases aparentemente apolíticas. "Os economistas ingleses, educados numa tradição cujas premissas filosóficas incluíam a doutrina da harmonia social e cuja inclinação política favorecia o livre comércio e um mínimo de intervenção governamental, viam sua ideologia individualista econômica sob crescente pressão nas décadas de 1870 e 1880" (Deane, 1980, p. 148).

Focalizando o caso inglês, Deane destaca que o paradigma neoclássico permitia aos economistas conciliar, de alguma forma, os preceitos liberais com a situação complexa de um capitalismo industrial urbano, em que a indústria britânica enfrentava concorrência internacional cada vez maior e em que o dogma da não-intervenção estatal na economia passava a ser revisto. Os economistas não são mais obrigados a comprometer-se com essas questões, justamente porque o raio de alcance da ciência econômica diminui: ela não mais tem a tarefa de fornecer explicações sobre os problemas de reprodução do sistema capitalista a longo prazo.

$\mathrm{O}$ que se quer aqui é indicar que Gudin, ao isentar a economia de qualquer responsabilidade pelas crises e instabilidades do século XX, está 
inserido numa tradição de pensamento segundo a qual à economia caberia um papel muito específico, qual seja, refletir sobre a alocação de recursos escassos. É nesse sentido que se compreende a dissociação radical entre economia e política. Gudin justifica suas posições com argumentos econômicos: a industrialização não deveria ser induzida, porque deslocaria artificialmente fatores produtivos, de modo a prejudicar a eficiência alocativa do sistema. A defesa da não-intervenção estatal era, portanto, "apolítica": o Estado não deve intervir, porque desviaria a economia do equilíbrio alocativo eficiente, que seria atingido, com certeza, sem intervenção. Não cabia à economia elevar um país à posição de grande nação industrializada, como queria Simonsen por meio da planificação. A inserção e o grau de desenvolvimento de um país dependeriam de sua dotação de fatores e da possibilidade de alocá-los com grau elevado de produtividade. "São esses índices de produtividade técnica que respondem pela prosperidade dos Estados Unidos e pelo alto padrão de vida de seu povo. Isso e não o seu protecionismo aduaneiro" (Gudin, 2010a, p. 116).

Gudin não discutia com profundidade os processos históricos, pois tais questões não estavam em seu escopo. Para Maringoni (2010, p. 76), inexiste, em Gudin, "a percepção dos interesses políticos e econômicos em jogo e as alternativas colocadas no tabuleiro." No geral, parece verdadeiro para Gudin que "se a equação falha, o problema estaria fora da alçada econômica" (Maringoni, 2010, p. 78). A entrada de Gudin no debate sobre as causas dos problemas brasileiros se dava pela via da economia em sentido estrito, mais especialmente da tradição neoclássica que estabelecera com a revolução marginalista. É uma entrada distinta a de Roberto Simonsen. A postura metodológica de Eugênio Gudin com relação à ciência econômica foi analisada por Maria Angélica Borges (1996, p. 22), que lhe atribuiu a percepção de que o objeto da ciência econômica é isolado das demais esferas da sociedade: por conseguinte, a ciência econômica em si teria um caráter autônomo, imune ao acontecer histórico. Segundo Borges (1996, pp. 132-133), essa inclinação metodológica -e ideológica- de Gudin é claramente reconhecível no debate com Simonsen.

\section{Simonsen e a perspectiva histórica}

No primeiro texto da controvérsia sobre o planejamento, Simonsen (2010a) constatava a situação de atraso da economia brasileira, sobretudo pelo fato de a renda nacional ser insuficiente para proporcionar aos cidadãos brasileiros um nível de vida aceitável. Destacava também a superioridade das nações industriais sobre as nações de "economia vegetal" e reconhecia a especificidade dos dois tipos de países. Ao comentar o relatório da Missão 
Cooke ${ }^{8}$ destacava o fato de terem os países industriais se desenvolvido com base em reservas de carvão mineral e minério de ferro, próximas umas das outras e dos grandes centros urbanos. Não sendo essa a situação brasileira, estava claro que o desenvolvimento do Brasil teria de se dar por meio de processos distintos dos que prevaleceram no século XIX.

Em sua réplica a Gudin, Simonsen (2010b) dá mais elementos de seu diagnóstico sobre o atraso brasileiro. Para o autor, o país não teria aproveitado os frutos do acelerado enriquecimento pelo qual passaram as nações industrializadas e em vias de industrialização durante o século XIX.

Na apreciação das evoluções verificadas em vários países impõem-se, cada vez mais, a nossa consideração, as profundas diferenciacõoes existentes entre as estruturas econômicas e sociais das nações consideradas ricas e das que se encontram em pronunciado atraso. [...] $\mathrm{Na}$ era vitoriana, se registrou um notável progresso europeu e norte-americano, e enquanto nas nações que lideraram esse surto o comércio cresceu sete vezes mais do que as suas populações, no Brasil verificou-se um impressionante paralelismo entre esses dois fatores (Simonsen, 2010b, p. 132. Cursivo nosso).

Simonsen discutia a situação da economia brasileira em termos bem diferentes dos adotados por Gudin. Sobre a era vitoriana, em que teriam vigorado os princípios da economia liberal, Simonsen apresentava a qualificação de que o progresso, que de fato existiu em parte do globo, não se distribuiu de maneira uniforme por todas as nações. Sobre esse período da economia liberal, afirma que "Se a escola liberal fixou, pela análise dos fatos sociais e econômicos, uma série de leis que predominavam no grande surto progressista verificado nas nações líderes do século passado, admite o relator [Gudin] a cristalização definitiva dessas leis" (Simonsen, 2010b, p. 154). As leis da economia liberal, que ceteris paribus conduziriam a humanidade pelo caminho da prosperidade, são questionadas de um ponto de vista histórico. A ideia fundamental de Simonsen era: enquanto algumas nações trilhavam um caminho, outras seguiam outra evolução, muito distinta, de forma que a suposta economia liberal associada à prosperidade existiu apenas para uma parte do mundo, num período específico. A ênfase do diagnóstico de Simonsen estava na particularidade histórica do desenvolvimento dos países de economia colonial e na situação desfavorável em que tais países se encontravam, devido justamente à função desempenhada por eles na evolução do capitalismo internacional.

${ }^{8}$ A Missão Cooke foi uma iniciativa de cooperação econômica entre Brasil e Estados Unidos, durante a segunda guerra (1942-1943). O objetivo da Missão era fazer um levantamento dos recursos disponíveis no Brasil, que pudessem ser aproveitados na conjuntura do conflito mundial. A Missão Cooke está associada aos esforços brasileiros para obter financiamento para projetos de infraestrutura, como a usina siderúrgica de Volta Redonda. 
Simonsen (1969) analisara em seu livro, ainda que brevemente, o estabelecimento do capitalismo europeu e a formação dos "grandes países agrícolas" a ele articulados. Ressalta como fatores importantes para o evolver do capitalismo, nos séculos XVIII e XIX, a intensificação do comércio e o afluxo de metais preciosos da América do Sul e, posteriormente, das minas norte-americanas e africanas. É clara a relação entre a situação da economia brasileira e o seu passado colonial, relacionado a uma inserção na divisão internacional do trabalho determinada pela evolução do capitalismo europeu, em sua fase de formação e em sua fase industrial. "É fruto também desse sistema econômico, a adoção, pelos grandes Estados, de definidas políticas coloniais, cuja interferência sofremos no passado e que ainda hoje atuam de modo inequívoco em nossa evolução, devido, principalmente, à natureza tropical da maioria de nossas produções" (Simonsen, 1969, p. 31. Cursivo nosso).

A ideia da especificidade histórica da trajetória das economias atrasadas ganha força com a crítica da concepção de que a evolução da economia mundial seria regida por leis, "cristalizadas" e imutáveis, as quais conduziriam a humanidade por uma rota de prosperidade, caso pudessem operar sem distúrbios extra econômicos. Simonsen criticava o fato de $\mathrm{Gu}$ din tomar como universais as leis da economia liberal, que regeriam o comportamento do homo economicus:

[Eugênio Gudin] não compreendeu que, pela contínua renovação da humanidade, pela transformação profunda por que passaram os povos, com os crescimentos demográficos, como os processos da ciência e da técnica e sob a influência dos ambientes geográficos, quem agora quiser compreender a possibilidade da existência de um desenvolvimento pacífico mundial, tem que substituir o egoísta homo economicus pelo moderno "homem social" que antepõe aos seus próprios os interesses da coletividade (Simonsen, 2010b, p. 154. Cursivo nosso).

Esse tipo de abordagem que privilegiava as especificidades históricas e que, portanto, permitia uma "transgressão" das leis econômicas que supostamente governariam o desenvolvimento era condição para que se pudesse solidificar um discurso industrializante. Ora, se as economias movem-se inexoravelmente numa determinada direção e essa direção é o caminho da prosperidade, não há margem para o desenvolvimentismo, entendido como uma ideologia ligada à alteração (induzida) da estrutura econômica de um país ou região, com vistas a melhorar as condições materiais de vida de seus habitantes (Bielschowsky, 2000, p. 7). Simonsen estava interessado na industrialização do Brasil, induzida pelo Estado e realizada com base na iniciativa privada e em investimentos públicos. Fica claro que a intenção industrializante do autor pressupõe que o rumo dos acontecimentos pode 
seguir um curso diferente daquela direção inexorável dada pelas supostas "leis" da economia. Se a situação de atraso é produto de uma evolução histórica específica -e não de uma vocação inata-, a situação pode ser modificada, se o curso dos acontecimentos for alterado por políticas concretas.

Essas ideias seriam importantes, no Brasil e em outros contextos nacionais, para legitimar propostas -teóricas e práticas- ligadas ao desenvolvimento dos países periféricos. Esse tipo de discussão do problema do atraso econômico em perspectiva histórica não era incomum em outros países "periféricos" à época. A obra do economista russo emigrado Sergei N. Prokopovicz (1871-1955), autor do livro L'industrialisation des pays agricoles (1945), que teve circulação no Brasil em tradução francesa, é um exemplo desse contexto mais amplo de debate em torno do atraso econômico de certas regiões em relação a outras - e das formas pelas quais a superação desse atraso se daria (Kojima, 2008, pp. 131-135 e Chyniaeva, 2001).

Se a ideia do atraso como forma histórica é relevante por dar sustentação a um tipo de proposta de política econômica que se solidificaria com a economia do desenvolvimento, cabe examinar as propostas de Simonsen para a economia brasileira, apresentadas no debate com Gudin. Tais proposições passavam pela direção da defesa da industrialização e do planejamento econômico. Na controvérsia, Simonsen procura se defender de duas críticas feitas por Gudin. A primeira é a associação entre planejamento e autoritarismo e a segunda, a falta de argumentos econômicos teóricos que justifiquem a adoção da planificação como estratégia de desenvolvimento. É com um propósito de legitimação diante dessas críticas que Simonsen recorreu à obra de Carl Landauer. A referência a Landauer é especialmente interessante por ter sido uma obra com a qual o autor teve contato no decorrer de seu debate com Gudin, como ficará claro em trecho abaixo.

Simonsen vê o plano como técnica, como meio de se chegar a um fim específico: a industrialização integrada. "O planejamento representa uma coordenação de esforços para um determinado fim" (Simonsen, 2010b, p. 134). No primeiro texto do debate, o autor analisa dados do Ministério do Trabalho sobre a renda nacional, que considera exígua, e refere-se aos problemas decorrentes do esforço de guerra, no Brasil e em outras nações. Os dados de Simonsen sobre a renda nacional foram alvo de vigorosa crítica de Gudin, que apontava imprecisões graves de mensuração. Simonsen, contudo, baseava-se nesses dados e em observações mais gerais para chegar à seguinte conclusão: "Impõe-se, assim, a planificação da economia brasileira em moldes capazes de proporcionar os meios adequados para satisfazer as necessidades essenciais de nossas populações e prover o país de uma estruturação econômica e social, forte e estável” (Simonsen, 2010a, p. 44).

Gudin (2010a, p. 55) citou o trecho acima, em sua resposta a Simonsen, para criticar vigorosamente a planificação, que considerava resultante 
de uma sucessão de desacertos, sobretudo de ordem política. Esse caos em que se atirara o mundo em consequência das guerras do século $\mathrm{XX}$ teria criado, para Gudin, um ambiente propício à mistificação do plano, no sentido de que este era apresentado como a solução de todos os problemas econômicos. É dessa crítica que Simonsen procurava se defender, ao insistir na atualidade e necessidade do plano, para superar a realidade presente: "É um erro supor que o conceito de planejamento se prenda a escolas políticas e econômicas antidemocráticas. [...] O Estado liberal vem planejando, de há muito e progressivamente. Se a expressão é nova, a realidade é velha" (Simonsen, 2010b, p. 134. Cursivo nosso).

O planejamento era apresentado como técnica, não necessariamente ligada a um tipo de governo, a qual poderia ser usada para alterar a realidade econômica de um país. Para Simonsen, o plano teria um caráter nacionalista: atuaria no interesse da "sociedade brasileira", não havendo filiação a uma tendência específica do espectro político. Tratava-se, acima de tudo, de uma técnica vista como atual, mais adequada à resolução aos problemas presentes do que os princípios da economia liberal, defendidos por Gudin. "[O planejamento] ainda não foi compreendido pelos 'saudosistas' que só querem enxergar os 'encantos' do século passado que, aliás, só puderam ser apreciados em algumas privilegiadas nações" (Simonsen, 2010 b, p. 153). Mesmo nessas nações ricas, argumentava Simonsen, a prosperidade proporcionada pela economia liberal só pôde ser usufruída por pequena parte de suas populações.

O caráter progressista e nacionalista que o plano assumia para Simonsen, não elimina traços conservadores de sua proposta.

[O planejamento econômico] cria um ambiente de segurança de tal ordem que facilita o melhor e mais eficiente aproveitamento da iniciativa privada, que está intimamente ligada ao conceito de propriedade. Nos países em que existe o sufrágio universal e onde a maioria dos votantes não é proprietária, a propriedade privada se manterá em sua plenitude enquanto essa maioria estiver convencida de que o exercício desse direito representa o verdadeiro interesse da sociedade em conjunto (Simonsen, 2010b, p. 135. Cursivo nosso).

O planejamento deveria, então, promover a riqueza nacional, mantendo a lei e a ordem, necessárias ao funcionamento da iniciativa individual e à manutenção da propriedade privada como instituto inquestionável. Não se deve esquecer que o contexto de final da guerra levava à reflexão sobre a estabilidade social. A URSS emergia como potência mundial e o socialismo, como sistema econômico, estava na ordem do dia. Um industrial como Roberto Simonsen certamente se via chamado a posicionar-se sobre essa questão. Seu raciocínio parece ser simples: se houver garantias 
mínimas de direitos sociais e um padrão de vida aceitável, as instabilidades sociais poderão ser evitadas.

Como se procurou mostrar, Simonsen entrava no debate sobre o desenvolvimento brasileiro a partir de uma perspectiva histórica. Não apresentava, em primeiro momento, uma teoria do planejamento, dando margem para duras críticas por parte de Gudin. Não havia uma argumentação rigorosa de que o planejamento poderia ser efetivo, do ponto de vista da teoria econômica. Simonsen estava ciente dessa necessidade e citou, em sua resposta a Gudin, o livro de Carl Landauer, publicado em inglês em 1944. "Após a apresentação do meu parecer ao Conselho Nacional de Política Industrial e Comercial, veio-me às mãos a notável obra do professor Carl Landauer, da Universidade da Califórnia, sobre a 'Teoria do Planejamento Econômico Nacional'”(Simonsen, [1945] 2010b, p. 135. Cursivo nosso).

Trata-se de uma tentativa de legitimar o planejamento, não só pela via de sua necessidade histórica, mas, também, pela via da teoria econômica. Com a referência a Landauer, Simonsen incluía, em sua réplica, elementos de uma discussão especificamente econômica. A principal justificativa apresentada por Landauer para a planificação era a existência do ciclo econômico, em que se alternam fases de depressão e ascensão. Segundo Landauer (1944, pp. 7-8), haveria muitas diferenças entre a "economia de mercado perfeito" que se ajusta automaticamente e a economia real.

Landauer destacava o fato de que haveria, na economia real, um desconhecimento, por parte dos agentes, dos resultados de suas ações. Segundo ele, os empresários não fazem seus projetos de investimento com base nos projetos de seus concorrentes e não sabem como serão as condições de mercado no futuro. Só se conhecerão os resultados da ação econômica algum tempo depois de executada. O sistema de preços não consegue coordenar perfeitamente as atividades econômicas individuais, já que reflete somente as condições atuais do mercado, incorporando fatores acidentais como a especulação. A planificação funcionaria, pois, como meio de oferecer aos agentes sinais mais estáveis sobre a economia.

Deve-se intervir no mecanismo do sistema de preços de modo que os preços presentes reflitam, com uma amplitude suficiente, a situação futura de oferta e demanda; ou se devem calcular antecipadamente os efeitos dos compromissos que os empresários projetam aceitar, e induzi- los a não levar em conta os preços atuais, na medida em que estes os levam a aceitar compromissos que não podem cumprir (Landauer, 1944, p. 8. Cursivo nosso).

O planejamento tem, com Landauer, uma justificativa econômica teórica, baseada na hipótese de que o sistema de preços não é um bom guia para o empresário elaborar seus projetos, que só se concretizarão no 
futuro, o que leva à ocorrência de depressões. Essa ideia seria compatível, segundo o próprio autor, com as formulações de Keynes. Landauer (1944, p. 15) é da opinião que a elaboração de Keynes sobre o ciclo é, na verdade, compatível com diferentes teorias do ciclo. $\mathrm{O}$ autor observava que a causa das depressões seria, para Keynes, a queda súbita da eficiência marginal do capital, mas o motivo dessa redução dos retornos esperados do capital permanece em aberto, havendo espaço para várias explicações.

Landauer apresentava uma definição de planificação, à qual Simonsen aludiu em sua réplica a Gudin. Esta definição, reproduzida abaixo, foi sublinhada por Simonsen no exemplar do livro de Landauer, pertencente à Coleção Roberto Simonsen, e traduzido do inglês para o português no segundo parecer da controvérsia do planejamento (Simonsen, 2010b, p. 135). Esse tipo de evidência confirma que Simonsen de fato estava buscando, em autores internacionais alinhados com seu projeto político-intelectual, elementos para a sua argumentação, em 1944-1945. "A planificação pode ser definida como a orientação das atividades econômicas por um organismo da comunidade, valendo-se de um projeto que descreve, em termos qualitativos e quantitativos, os processos de produção que devem ser levados a cabo durante um período determinado do futuro" (Landauer, 1944, p. 13). ${ }^{9}$

Se os projetos a serem levados a cabo são planificados, elimina-se a causa fundamental do ciclo -e das depressões- que era a impossibilidade de se antecipar as consequências das ações econômicas. Com o plano, o futuro se torna previsível, não havendo os descompassos entre oferta e demanda ou entre inversões e disponibilidade de recursos, que caracterizam as depressões cíclicas. Discutida a possibilidade teórica de o planejamento eliminar o ciclo econômico, Landauer passava a considerações de caráter técnico e político-ideológico relativas à elaboração e execução do plano, às quais Simonsen se referiu brevemente: "[Landauer] aconselha a manutenção da produção em mãos da iniciativa privada e, para a execução do planejamento, acredita mais nos meios suasórios do que nos compulsórios" (Simonsen, 2010b, p. 135).

A democracia e os regimes de governo ocupam lugar central no livro de Landauer: a ação econômica deveria ser usada como meio de evitar as ditaduras e os totalitarismos. Nesse ponto, há uma convergência com Simonsen. Ambos os autores estavam preocupados com a situação das economias no pós-guerra. Viam a necessidade de assegurar melhores condições de vida aos cidadãos, para evitar uma quebra traumática da insti-

\footnotetext{
${ }^{9} \mathrm{O}$ exemplar da Coleção Roberto Simonsen foi sublinhado e anotado por Simonsen em vários trechos cuja temática está diretamente relacionada com os argumentos mobilizados na controvérsia do planejamento.
} 
tucionalidade, nos moldes daquela que o mundo estava vivendo com a segunda guerra. Ambos convergiam no ponto de que o desenvolvimento -ou o desenvolvimento planejado, para Landauer- afastaria as possibilidades de ruptura, tanto fascista quanto revolucionária, da institucionalidade democrática.

Landauer não tinha uma elaboração que se referisse especificamente aos países atrasados: procurava legitimar o planejamento como categoria geral, como forma de estabilizar economias por natureza instáveis. A preocupação de fundo, que parece orientar Roberto Simonsen e Landauer, é a ideia progressista de que algo deveria ser feito, no sentido da melhoria das condições materiais das nações, para que não se repetissem as tragédias vividas pelo mundo ocidental no período que Hobsbawm (1995) chama de "era da catástrofe". Nesse sentido, a discussão pioneira de 1944-1945 no Brasil -e as elaborações de Simonsen em particular- parecem estar em sintonia com essa discussão internacional sobre a situação econômica dos países no pós-guerra e como se deveria agir sobre ela. O campo da economia do desenvolvimento, que se firmaria como vertente teórica importante da ciência econômica no século XX, certamente está imbuído dessas questões que Simonsen e Gudin, em sintonia com Landauer e outros autores internacionais, discutiram pioneiramente no Brasil, nesse momento crítico do final da segunda guerra.

\section{CONSIDERAÇÕES FINAIS}

Uma leitura ligeira dos documentos que constituem a controvérsia do planejamento, feita no presente e informada pelo atual quadro de desenvolvimento da teoria econômica, poderia deixar a impressão de que Simonsen não estava tão bem armado tecnicamente quanto Gudin para a discussão econômica. Essa leitura, todavia, desconsidera certas dimensões captadas por uma perspectiva de história das ideias, e mais que isto, desconsidera aspectos também teóricos, mas de outro espectro analítico, contidos na perspectiva de Simonsen. Vale lembrar que, no momento em que se dava a controvérsia, a elaboração de Simonsen não era reconhecidamente menos sofisticada ou menos válida que a de Gudin. Gudin via em Simonsen um interlocutor à altura: por mais que discordasse de suas posições, não via o debate como inútil, pelo contrário. Esse reconhecimento mútuo, por parte dos dois contendores, da legitimidade da argumentação do oponente desautoriza a visão de que uma abordagem que se apoia na história econômica era, naquele momento, menos relevante ou menos bem-fundamentada do que uma abordagem mais relacionada a questões de eficiência alocativa. 
A entrada de Simonsen no debate se dava por um caminho distinto daquele percorrido por Gudin: era uma incursão pela via da história econômica e da defesa da industrialização planejada. Essa incursão no debate, baseada nos estudos pioneiros realizados pelo autor no campo da história econômica do Brasil, era coerente com sua trajetória intelectual e enfatizava, de forma original, a especificidade da evolução econômica brasileira, marcada pelo colonialismo e pelo vínculo periférico ao capitalismo internacional. Simonsen articulava sua discussão sobre as causas históricas do atraso à proposição do planejamento como instrumento para se atingir o desenvolvimento econômico e para se garantir a ordem democrática. Esse tipo de articulação estava em sintonia com as discussões que se desenrolavam no final da segunda guerra, da qual emergia um mundo que se interrogava sobre as razões do caos econômico e político em que estivera imerso e sobre as formas de se evitar a repetição de tal situação. Ademais, a abordagem de Simonsen contribuiu para dar condições de possibilidade ao discurso e às reivindicações dos grupos industrialistas no Brasil, robustecendo a proposição de políticas econômicas e a formulação de novas ideias. Vale lembrar, mais uma vez, a clara influência da abordagem de Simonsen sobre a elaboração histórica de Celso Furtado em Formação econômica do Brasil.

A contribuição de Simonsen à controvérsia do planejamento tem, portanto, uma dimensão singular na história das ideias econômicas brasileiras. Essa singularidade vem à tona quando o debate é analisado numa perspectiva de história das ideias. Vista desse ângulo, a participação de Simonsen revela-se marcada pela originalidade da percepção dos problemas econômicos a partir de uma perspectiva histórica e pela sintonia com autores coevos, dentro de um ambiente internacional de ideias em que questões como a industrialização de países atrasados e o planejamento econômico estavam na ordem do dia. Isso torna sua contribuição importante para que se identifiquem os traços de um pensamento econômico brasileiro em formação, inserido nesse ambiente de ideias.

\section{LISTA DE REFERÊNCIAS}

Bastos, P. P. Z. (2012). O projeto nacionalista de Vargas. Em P. P. Z. BAstos e P. C. D. Fonseca (orgs.), A Era Vargas: desenvolvimentismo, economia e sociedade. São Paulo: Universidade Estadual Paulista.

Bielschowsky, R. (2000). Pensamento econômico brasileiro: o ciclo ideológico do desenvolvimentismo ( $4^{\mathrm{a}}$ edição). Rio de Janeiro: Contraponto.

Blaug, M. (1962). Economic theory in retrospect. Homewood, Ill.: Richard D. Irwin. 
Boianovsky, M. (2011). Friedrich List and the economic fate of tropical countries. Em Social Science Research Network. Recuperado de http://ssrn.com/abstract=1810846

Borges, M. A. (1996). Eugênio Gudin: capitalismo e neoliberalismo. São Paulo: Pontificia Universidad Católica de São Paulo.

Cardoso, J. L. (2003). The international diffusion of economic thought. Em W. SAMUEls, J. Biddle e J. DAVis (eds.), A companion to the history of economic thought. Oxford e Nova Iorque: Blackwell.

Cardoso, J. L. (2009). Reflexões periféricas sobre a difusão internacional do pensamento econômico. Nova Economia, 19(2).

CEPÊDA, V. A. (2003). Roberto Simonsen e a formação da ideologia industrial no Brasil: limites e impasses (tese de doutorado). São Paulo, Universidade de São Paulo.

Chinyaeva, E. (2001). Russians outside Russia: the émigré community in Czechoslovakia, 1918-1938. München: Oldenbourg Verlag.

Deane, P. (1980). A evolução das ideias econômicas. Rio de Janeiro: Zahar.

Dias, S. (2001). Roberto Simonsen. Em Dicionário histórico-biográfico brasileiro: pós-1930. (2a. edição, pp. 5481-5485). Rio de Janeiro: Fundação Getulio Vargas/Centro de Pesquisa e Documentação de História Contemporânea do Brasil.

Diniz, E. (2004). A progressiva subordinação das oligarquias regionais ao governo central. Em T. SZmrecsánYi e R. G. Granziera (orgs.), Getúlio Vargas e a economia contemporânea (2a. edição rev. e ampl). São Paulo: Hucitec.

Doellinger, C. Von (2010). Introdução. Em R. Simonsen, E. Gudin e C. Von DoELLINGER, A controvérsia do planejamento na economia brasileira (3a. edição). Brasília: Instituto de Pesquisa Econômica Aplicada.

Draibe, S. (1985). Rumos e metamorfoses: um estudo sobre a consituição do Estado e as alternativas de industrialização do Brasil. Rio de Janeiro: Paz e Terra.

Fanganiello, H. (1970). Roberto Simonsen e o desenvolvimento econômico. São Paulo: Faculdade de Economia, Administração e Contabilidade/Universidade de São Paulo.

FAusto, B. (2010). A revolução de 1930: historiografia e história (16a. edição). São Paulo: Companhia das Letras.

FonseCA, P. C. D. (janeiro-março, 2003). Sobre a intencionalidade da política industrializante do Brasil na década de 1930. Revista de Economia Política, 23(1).

Grossman, G., Grether, E. T. e Letiche, J. (1985). 1985, University of California: In Memoriam. Berkeley: University of California Academic Senate. Recuperado de http://texts.cdlib.org/view?docId=hb4d5nb20m\&doc.view=frames\&chunk. id=div00092\&toc.depth=1\&toc.id=

Gudin, E. (1956). Princípios de economia monetária (2a. edição). Rio de Janeiro: Agir.

Gudin, E. (2010a). Rumos de política econômica. Em R. Simonsen, E. Gudin e C. Von Doellinger, A controvérsia do planejamento na economia brasileira (3a. edição). Brasília: Instituto de Pesquisa Econômica Aplicada.

Gudin, E. (2010b). Carta à Comissão de Planejamento. Em R. Simonsen, E. Gudin e C. Von Doellinger, A controvérsia do planejamento na economia brasileira (3a. edição). Brasília: Instituto de Pesquisa Econômica Aplicada. 
Hagemann, H. (2001). The Verein für Sozialpolitik from its foundation until World War I. Em M. Augello e M. Guidi (eds.), The spread of political economy and the professionalisation of economists. Economic societies in Europe, America and Japan in the nineteenth century. Londres: Routledge.

Hobsbawm. E. (1995). Era dos extremos: o breve século XX. São Paulo: Companhia das Letras.

Keller, V. (2001). Eugênio Gudin. Em Dicionário histórico-biográfico brasileiro: pós-1930 (2a. edição). Rio de Janeiro: Fundação Getulio Vargas/Centro de Pesquisa e Documentação de História Contemporânea do Brasil.

Kojima, S. (2008). Exiled Russian economists and the USSR: Brutzkus and Prokopovich. Em V. BARnetT e J. Zweynert (ed.), Economics in Russia: studies in intellectual history. Aldershot: Ashgate Publishing.

LANDAuer, C. (1944). Theory of national economic planning. Berkeley: University of California. [Exemplar pertencente à Coleção Roberto Simonsen, Universidade Estadual de Campinas.]

Lima, H. F. (1963). Mauá e Roberto Simonsen: dois pioneiros do desenvolvimento. São Paulo: Edaglit.

Lima, H. F. (1976). Três industrialistas brasileiros: Mauá, Rui Barbosa e Simonsen. São Paulo: Alfa-Ômega.

LOvE, J. (1995). Economic ideas and ideologies in Latin America since 1930. Em The Cambridge history of Latin America, volume 6: 1930 to the present, part 1: Economy and society. Cambridge: Cambridge University Press.

Luz, N. V. (1975). A luta pela industrialização brasileira (2a. edição). São Paulo: Alfa-Ômega.

Manoilescu, M. (2011). Teoria do Protecionismo e da Permuta Internacional. Rio de Janeiro: Cepax Dei.

Maringoni, G. (2010). Liberalismo radical. Em A. Teixeira, G. Maringoni e D. L. Gentil. Desenvolvimento: o debate pioneiro de 1944-1945. Brasília: Instituto de Pesquisa Econômica Aplicada.

Prokopovicz, S. N. (1945). L'industrialisation des pays agricoles et la structure de l'économie mondiale après la guerre. Neuchâtel: Éditions de la Baconnière.

Rodrigues, C. H. L. (2005). A questão do protecionismo no debate entre Roberto Simonesen e Eugênio Gudin (dissertação de mestrado). Campinas, Universidade de Campinas.

SAES, F. A. M. (2009). Industrialização e desenvolvimento na perspectiva de duas gerações de pensadores brasileiros: Roberto Simonsen e Celso Furtado. Em F. S. Coelho e R. G. Granziera, Celso Furtado e a formação econômica do Brasil: Edição Comemorativa dos 50 Anos de Publicação (1959-2009). São Paulo: Atlas.

Schumpeter, J. A. (1954). History of economic analysis. Nova Iorque: Oxford University Press.

Simonsen, R. C. (1969). História econômica do Brasil (1500-1820) (6a. edição). São Paulo: Companhia Editora Nacional. 
Simonsen, R. C. (2010a). A planificação da economia brasileira. Em R. Simonsen, E. Gudin e C. Von Doellinger, A controvérsia do planejamento na economia brasileira (3a. edição). Brasília: Instituto de Pesquisa Econômica Aplicada.

Simonsen, R. C. (2010b). O planejamento da economia brasileira -Réplica ao Sr. Eugênio Gudin. Em R. Simonsen, E. Gudin e C. Von Doellinger, A controvérsia do planejamento na economia brasileira (3a. edição). Brasília: Instituto de Pesquisa Econômica Aplicada.

Tribe, K. (2009). Historical Schools of Economics: German and English. Em W. J. Samuels, J. E. Biddle e J. B. Davis (eds.). A companion to the history of economic thought. Malden: Blackwell. 